


\section{Insite: Right Answer, Wrong Question}

\section{Gillian Calder*}

\section{The Wrong Question}

I have entitled my five-minute comment: "Insite: Right Answer, Wrong Question."1 The focus of my comments is on the division-of-powers approach used in the reasoning of Justice Huddart of the British Columbia Court of Appeal. Although asked to determine whether the legislative regime at issue was enacted validly, that is, whether it was either federal or provincial-the question that she wanted to answer, and did answer, was whether the matter should be federal or provincial. My reading of the majority reasons is that Justice Huddart (with Justice Rowles concurring) used the doctrine of interjurisdictional immunity ("IJI") to reach the conclusion that she deemed to be the just outcome-that "the supervision of self-injections of illegallypossessed drugs in a provincially authorized and supported health care facility is dictated by the public interest in health care"2 and thus falls exclusively within provincial jurisdiction.

The use of IJI to reach this conclusion raises several concerns for me that are worth exploring further. First, the answer given by the court was grounded in one of the most inflexible aspects of constitutional law and continues the formal divide between division of powers and the Charter. Why is it that when courts are asked to analyze whether an issue is properly enacted by either the federal government or one of the provincial governments, the interpretative analysis used is rarely informed by Charter or section 35 jurisprudence? ${ }^{3}$ Second, the use of IJI seems to offer renewed life to a "watertight compartments" approach to federalism. Of the differing metaphors that have emerged in case law to describe the division of powers in the
Constitution Act, $1867^{4}$ over the past century and a half of jurisprudence, the "ship of state" approach remains the most rigid and, notwithstanding an emphasis on human ingenuity, ${ }^{5}$ an inaccessible choice. Third, the approach leaves health hived off within provincial jurisdiction in a manner that raises some troubling questions with respect to other contentious health issues such as abortion. ${ }^{6}$ In this comment, I will speak to the first issue and hope that the other questions will be addressed in the insights of my colleagues, in the conversation around this volume, and in future judicial decisions.

\section{The context}

Over the past ten years I have explored systemic questions about the relationship between women, work and social reproduction in Canada through a feminist lens, primarily by examining the legal mechanisms through which the federal government delivers a benefit for maternity and parental leave. ${ }^{7}$ This work coalesced, to some extent, with a judgment of the Supreme Court of Canada in October 2005 when, in a case similar to Insite, the Court offered a fairly straightforward answer to the division of powers question. ${ }^{8}$ The end result there too was ultimately "correct," but in the process the Court sidestepped answering the more pressing social questions. ${ }^{9}$ This pushed me to question further why we limit assessment of constitutionality in a jurisdictional sense to a textual assessment of which level of government-the federal or the provincial-can legislate on a particular subject matter. Why don't we use a different approach to constitutionalism, one in which "arid legal formalism [is] rejected in favour of an interpret- 
ive stance under which the scope of the power is considered in light of the principles underlying the whole of our constitutional structure"? ${ }^{10}$ The most important questions that underlie Insite are the ones that centre on the needs of people who use that care facility's resources. What do we lose when we turn to division of powers to answer the most dynamic questions we can ask as a society?

\section{Three stories}

In Insite, the British Columbia Court of Appeal addresses the division of powers question in an aridly formal way. The majority finds that its supervised drug injections services are "vital" and that determining the kinds of services a hospital provides is at the core of its purpose. ${ }^{11}$ Because the federal legislation at issue would impair Insite's work, it should not apply.

Instead of focussing on the text of sections 91 and 92, what if the Court had answered the question by interpreting the provisions at issue as the Supreme Court of Canada directed in the Québec Secession Reference with attention to the foundational unwritten principles that ground and inform the workings of Canadian constitutional law? ${ }^{12}$ What would explicit attention to federalism, democracy, constitutionalism and the rule of law, and respect for minorities enable the Court to highlight? ${ }^{13}$ Or, following the work of Patricia Hughes, what analysis would come from centring on substantive equality, giving the most nuanced understanding of equality the same foundational constitutional status as freedom of speech or judicial independence? ${ }^{14}$ Or, wisely taking the advice articulated by Hester Lessard in this volume, what other ways of seeing might emerge from an analysis of division of powers questions "textured by critical oppositional politics and by the democratic engagement of politically marginalized groups that takes place outside established channels of power"? ${ }^{15}$

My assertion here is not that the result from the British Columbia Court of Appeal would ultimately have been different. I think they came to the just result. But by answering the question with reference only to the strict textual reading of the Constitution, this case ends rather than prompts a more dynamic understanding of the role of law (or, the fuller role of law) in deciding these kinds of disputes. To make this argument more apparent, I will compare the result in Insite with three other division of powers cases in which the Court chose a formal approach to federalism to answer the question posed, leaving other questions of equality and colonialism unexplored.

\section{a. Pauline Paul-Paul v Paul ${ }^{16}$}

The first story is the story of Pauline Paul, a member of the Tsartlip First Nation who in 1984 commenced divorce proceedings against her husband of nineteen years. Mrs. Paul sought an interim order pursuant to British Columbia's Family Relations Act that would allow her to live in their matrimonial home on her own with her children until division of property was determined. Her situation was heightened by the fact that she was escaping a violent relationship. Mr. Paul contested the application, relying on the argument that jurisdiction over matters pertaining to Indians and lands reserved for Indians were exclusively matters of federal jurisdiction. On a strict division of powers analysis, the Supreme Court of Canada (SCC) sided with Mr. Paul, finding the provincial legislation inapplicable to a family residence located on land in an Indian Reserve. As Mary Ellen Turpel has written, the Court gave no analysis of the gap this leaves in the present scheme, and does not even mention the violence that is present in Mrs. Paul's relationship. In the process of applying a strict federalism analysis, the SCC effectively erased the social and political context of the dispute. The tools it used to answer the question left Turpel and others concluding, "why this is a division of colonial powers and not a matter of aboriginal custom regarding family breakdown and land consequences is lost on the courts." 17

\section{b. Réjean Demers-R $v$ Demers $^{18}$}

The second case is the story of Réjean Demers, a young man living with Down Syndrome, charged with sexual assault, but found permanently unfit to stand trial on account of his mental disability. However, under the Criminal Code of Canada he was subject to indefinite appear- 
ances before a Review Board, and did not have access to an absolute discharge-unlike other accused who go through a trial and are found not criminally responsible by reason of mental disorder. M. Demers challenged the statutory regime on several bases, including that the provisions establishing a regime for dealing with accused persons living with mental disabilities were beyond the federal government's criminal law power. On this issue, the Supreme Court of Canada, with LeBel J in dissent on this point, held that in pith and substance these provisions fell within both the preventative and criminal procedures branch of the criminal law, all wellaccepted criminal law purposes. As such, they were within the jurisdiction of the federal government. Using this division of powers analysis, the needs of persons with mental disabilities in conflict with the law who are unable to establish their legal culpability through the trial process, is outside the Court's purview.

\section{c. Maternity and Parental Leave-EI Reference $^{19}$}

Finally, in this 2005 reference case, the government of Québec asked the Supreme Court of Canada whether maternity and parental leave, while related to employment, was not in fact a matter attached to (un)employment insurance (a federal matter), or whether it was more properly a social program (a provincial matter) ${ }^{20}$ In saving the regime as valid federal law, the Court left unexplored whether the benefit, delivered as it is through unemployment insurance, is failing marginalized Canadians who arguably need the benefit the most. As Nitya Iyer has argued, a benefit that is disproportionately available to certain women based on their labour force participation exacerbates the oppression of poor women, Indigenous women, women of colour, women with disabilities, single parents and lesbian parents-by making it easier for mothers with certain labour patterns to qualify for benefits. ${ }^{21}$ The judgment seems to close the door on the more complicated question of whether the maternity and parental leave benefit program is properly rooted in principles outside of unemployment insurance. To most of us working in the area, ${ }^{22}$ it seemed that the Court was being asked the wrong question. Given the nature of the division of powers analysis, as with Mrs. Paul and M. Demers, the substantive equality questions that inform this debate were left unaddressed.

\section{Crafting the right question}

I have argued that division of powers analysis is often rigid, and as a result, existing gaps in legislative frameworks, such as the absence of a culturally sensitive means by which Aboriginal women can seek division of matrimonial property on reserve in Canada, or questions with respect to whether the Criminal Code ${ }^{23}$ or the federal Employment Insurance Act ${ }^{24}$ is meeting the equality needs of marginalized Canadians, are not considered, or are left unexplored. It is a crucial question for constitutional law that remains unanswered: whether assessment of constitutionality in a jurisdictional sense should be limited to a textual assessment of which level of government-the federal or the provincial-can legislate a particular subject matter, or whether an interpretive stance that considers the scope of the power at issue in "light of the principles underlying the whole of our constitutional structure" should be adopted. ${ }^{25}$ The outcome in the case of Insite, where attention was paid to the unwritten constitutional principles of federalism, democracy, constitutionalism and the rule of law, protection of minorities, and substantive quality, would arguably have been the same. However, the result of coming to this conclusion by cementing walls around an area of provincial jurisdiction means both that this decision is being appealed with a different outcome possible, and that conclusions of this nature can be reached in the future without exploring the very systemic questions that make this facility necessary for people living with addictions in the first place. The right question may be more important than the right answer. Ultimately, the right to access services at Insite is an issue that invokes the necessities of life for the most marginalized Canadians. Surely the use of constitutional law to answer this critical and systemic question should not lead to a formal, arid, and dehumanized response.

Law is performative-a dynamic and constantly shifting medium that profoundly shapes 
our understandings of citizenship, gender, social condition and community. The use of IJI to help reach the result that Insite should continue to exist and offer on one level the necessities of life and on the other the hope of systemic change, is laudable. However, the risk of shutting down solutions rather than enabling them in this context is too great. The British Columbia Court of Appeal came to the conclusion that the relevant provisions of the federal Controlled Drugs and Substances Act should not apply to the work done at Insite. ${ }^{26}$ Crafting the right question so that the human issues of what it means to live with addiction and poverty in one of the most privileged societies in the world do not get lost in a determination of exclusive jurisdiction is essential.

\section{Notes}

* Associate Professor, Faculty of Law, University of Victoria.

1 This case comment will refer solely to PHS Community Services Society $v$ Canada (Attorney General), 2010 BCCA 15, 314 DLR $\left(4^{\text {th }}\right) 209$, rev'g 2008 BCSC 661, 293 DLR $\left(4^{\text {th }}\right) 392$, leave to appeal to SCC granted, 33556 (June 24, 2010) [Insite].

Thank you to Jen Raso for excellent research assistance and to the audience at Kent University on June 30, 2006, who first responded to this series of stories in relation to each other. Thank you also to Rebecca Johnson, Andrew Petter, Nola Ries, Jeremy Webber, Benjamin Berger, Hester Lessard and the assembled audience for this panel on the judgment for this conversation. Thank you specifically to Tim Richards whose work to provide students with the most dynamic way to engage with the questions underlying the legal challenges faced by the Insite facility was inspiring.

2 This was the argument made by the provincial Attorney General, and cited by Justice Huddart, ibid at para 120 .

3 This refers to the large body of case law and scholarly analysis surrounding the Canadian Charter of Rights and Freedoms, Part I of the Constitution Act, 1982, being Schedule B to the Canada Act 1982 (UK), 1982, c 11 [the Charter] and s 35 of the Constitution Act, 1982 (ibid).
4 (UK), 30 \& 31 Vict, c 3, reprinted in RSC 1985, App II, No 5, ss 91-92.

5 Donna Greschner, “The Supreme Court, Federalism, and the Metaphors of Moderation" (2000) 79 Can Bar Rev 47 at 53.

6 See the discussion by Hester Lessard in "Jurisdictional Justice, Democracy and the Story of Insite," in this volume.

7 See e.g. "The Personal is Economic: Unearthing the Rhetoric of Choice in the Canadian Maternity and Parental Leave Benefit Debates" in Rosemary Hunter and Sharon Cowan, eds, Choice and Consent: Feminist Engagements with Law and Subjectivity (New York: Routledge-Cavendish, 2007) at 125; "A Pregnant Pause: Federalism, Equality and the Maternity and Parental Leave Debate in Canada” (2006) 14:1 Fem Legal Stud 99; "Recent Changes to the Maternity and Parental Leave Benefits Regime as a Case Study: The Impact of Globalization on Social Programs in Canada" (2003) 15:2 CJWL 342; and Gender, Social Reproduction and the Canadian Welfare State: Assessing the Recent Changes to the Maternity and Parental Leave Benefits Regime (LLM thesis, York University, 2002) [unpublished]. Reference re Employment Insurance Act (Can), ss 22 and 23, 2005 SCC 56, [2005] 2 SCR 669 [EI Reference].

9 Calder, "A Pregnant Pause," supra note 7 at 116-17.

$10 R v$ Demers, 2004 SCC 46, [2004] 2 SCR 489 at para 78 , LeBel J, dissenting on this point.

11 Insite, supra note 1 at para 157.

12 See Reference re Secession of Québec, [1998] 2 SCR 217, 161 DLR (4th) 385.

13 Here I am indebted to the work of John Borrows, and in particular, "Sovereignty's Alchemy: An Analysis of Delgamuukw v. British Columbia" (1999) 37:3 Osgoode Hall LJ 537 at 589-96.

14 Patricia Hughes, "Recognizing Substantive Equality as a Foundational Constitutional Principle" (1999) 22 Dal LJ at 5.

15 Hester Lessard, supra note 6 at 108.

16 [1986] 1 SCR 306, 26 DLR (4th) 196.

17 Mary Ellen Turpel, "Home/Land" (1991) 10 Can J Fam L 17 at 24.

18 Supra note 10.

19 Supra note 8.

20 For a discussion of the motivations underlying the challenge brought by the government of Québec, see: Calder, "The Personal is Economic" supra note 7, and Calder, "A Pregnant Pause," supra note 7.

21 See Nitya Iyer, "Some Mothers Are Better than Others: A Re-examination of Maternity Benefits" 
in Susan B Boyd, ed, Challenging the Public/ Private Divide: Feminism, Law, and Public Policy (Toronto: University of Toronto Press, 1997) 168 at 176 , as cited in Calder, "The Personal is Economic," supra note 7 at 134-35.

22 My work on maternity and parental leave has been greatly informed by many Canadian legal feminist scholars engaging with similar questions. See e.g. the work of Bev Baines, Gwen Brodsky, Susan Boyd, Barbara Cameron, Michèle Caron, Andrée Côté, Rachel Cox, Shelagh Day, Judy Fudge, Nitya Iyer, Ann Porter, Chantal Richard, Ruth Rose, and Lorna Turnbull.

23 RSC 1985, c C-46.

24 SC 1996, c 23.

$25 R v$ Demers, supra note 10 at para 78. Pointing to these principles also at paras 79, 83-84, LeBel J

alludes to Reference re Secession of Québec, supra note 12 .

26 Insite, supra note 1 at para 193. 